\title{
Revisiting Young Customers' Bank Selection and Loyalty Decisions in Ghana
}

\author{
By Hadi Ibrahim* ${ }^{*}$ Ibn Kailan Abdul-Hamid ${ }^{\dagger} \&$ Muhammed Abdulai ${ }^{*}$
}

This study examines first-year students' (who mostly are opening/operating bank accounts for the first time on their own) bank selection and loyalty decisions. An extensive literature review was done to develop study instruments. An exploratory analysis of 320 usable questionnaires was done. The study found in order of importance that: bank service/convenience, service quality/bank image, staff attitude/recommendations, core service/communication and customer service were factors influencing their bank selection decisions in Ghana. Also, friendly operations/regulations, relationship management, service quality/ financial benefits, client satisfaction and bank image were identified in order of importance to be responsible for their loyalty to banks in Ghana. This study reiterates to bank management that factors including quality of service, bank image, recommendation (word of mouth), employee competence, bank knowledge, customer satisfaction, price of transactions, relationship marketing and bank regulation should be at the core of their strategy development and implementation. The study is original with insightful updates and new perspectives on young adults' bank selection and loyalty dimensions. This study is the first attempt to systematically combine bank selection and loyalty factors in a single comprehensive survey in Ghana. (JEL G21)

Keywords: bank, customers, Ghana, loyalty, selection

\section{Introduction}

The level of interconnectivity and interdependence in the world today precipitated by globalisation is unprecedented. The effects of this on financial services marketing, especially banks, is the sophisticated young customers who are well-informed and turn to be fickle/fluid because they take cues and clues from any part of the globe. There is also the proliferation of service-oriented firms, especially financial service's sector firms who are into the provision of full banking services (Maudos, 2017, Cummins Rubio-Misas and Vencappa, 2017). For instance, in Africa, the emergence of 'mobile money' is a clear point of reference where mobile telecommunication companies are going into money transfers and safekeeping of monies in mobile phones wallets with interest earnings to customers. MTN Mobile Money in Ghana, a market leader in this new drive, recorded about GHपC 23 billion in mobile money transactions value in 2016 with 8.5 million subscribers (Capitalgroupghana.com 2017).

\footnotetext{
*Commercial Officer, Ministry of Trade and Industry, Ghana.

'Lecturer, University of Professional Studies, Accra, Ghana.

${ }^{t}$ Lecturer, University for Development Studies, Nyankpala Campus, Tamale, Ghana. PhD Candidate, Tallinn University, Tallinn, Estonia.
} 
Currently, subscribers to this service can receive remittance or international money transfer abroad directly via these platforms without any home bank involvement. It came as no big surprise when within a span of two years, three indigenous banks in Ghana were declared by the central bank (Bank of Ghana) as distress and insolvent (Graphic Online 2017). Subsequently, in an endeavour to ensure resilient and robust banking sector, a total of 16 banks suffered revocation of licenses and compelled mergers by Bank of Ghana (Ghanaweb 2019). More so, 386 microfinance and microcredit firms experienced similar revocation of permits by the central bank (Myjoyonline 2019). In the Nordic countries, current trends of new small entities taking to new strategies of using the internet as the main distribution, marketing and communication channels in offering a full competitive range of banking services other than extensive physical branch networks is a distinct reality (Nordic Competition Authorities 2006).

The preceding demonstrates that the steep competition characterising the banking sector is not only internal but external as well and ubiquitous. Therefore, the future of retail banking will continue to be challenging and paradoxical with the question of whether future customers will still need bank services (Ibrahim 2014). The determination of the way forward remains with the banks to prove their continuous relevance beyond today by attracting young customers. Some researchers support mass marketing of financial services but in a competitive environment, selecting key segments and strategically concentrating marketing efforts towards serving them better is superior. Conceptual postulations on successful segmentation hold that the segment must be measurable, substantial, accessible, unique and actionable (Lees and Winchester 2018). Youth as a market segment is noted to be growing phenomenally in some parts of the world, particularly in Africa. It is estimated that about two-thirds of youth engage in active work with significant incomes and substantial earning potential far more than average lifetime earnings making them highly lucrative segment (Singh et al. 2018). This segment is characteristically creative, venturesome, and curious who turn to experiment with new things with a high potential of building a long relationship with banks (Chan et al. 2017). The youth segment of the population is growing leaps and bounds in Africa, which is considered as the greatest asset for Africa and estimated to double to more than 830 million by 2050 (AfDB 2016).

Instructively, this trajectory demands a proactive evidence-informed strategic response with updated and penetrating insights on factors underpinning youth initial bank selection and loyalty decisions. Even though such studies have been done in the area of bank selection and loyalty in Ghana (Narteh 2013, Abdul Mumin et al. 2012, Blankson et al. 2009, Narteh and Owusu-Frimpong 2011, Hinson et al. 2013) and the world over (Katircioglu et al. 2011, Sayani and Miniaouti 2013), new and sophisticated technologies is rapidly changing and predicting taste and preferences of customers, particularly the youth. It has made existing studies on bank selection and loyalty not only transient but outdated and inapplicable in many contexts (Nkamnebe et al. 2014). It is against this backdrop of shifts in the social, economic and technological milieu that this study is focusing on revisiting the youth bank selection and loyalty study by exploring the 
critical factors considered to be the most crucial in influencing today's youth decisions drawing data from University of Ghana students in Ghana.

Necessarily, findings from this study will make a substantial and original contribution both at the theoretical and empirical level to current literature. Thus, it will add knowledge to a proper conception and orientation as well as support and enrich theories and or models of youth bank selection and loyalty decisions, especially in a developing country. By so doing, invaluable new and far-reaching insights that are evidenced-informed will be provided to assist bank managers in optimising marketing efficiencies.

\section{Literature Review}

This review, among other things, seeks to update the extant literature and to achieve that, recent literature will be reviewed under the sub-themes: youth bank selection decisions and development, factors impinging on bank loyalty decisions and rational choice theory and competition theory.

\section{Youth Bank Selection Decisions and Development}

The genesis of premier research on bank selection criteria takes its roots from the works of researchers such as Anderson et al. (1976), Evans (1979), Kazeh and Decker (1993), Hejazi (1995) and Metawa and Almossawi (1998). These studies were focused on identifying the dominant factors impinging on bank selection decisions a priori to segmentation of the bank customers. As competition intensifies, customers getting increasingly sophisticated and fickle and technologies unleashing new and better ways of doing things, bank marketers have segmented the markets to tailor its products to suit the various segments' needs. Also, previous selection criteria were fundamentally on rates, fees, bank charges and proximity to banks (Ibrahim 2014) but today, the focus is shining on service excellence, streamline services and innovative products using technologies of the internet.

For this reason, we have studies abound concentrating on segments such as gender by Ukenna and Nike (2012), multiple bank users by Mokhlis et al. (2011), students by Almossawi (2001), Gerrard and Cunnigham (2011), Mahmoud et al. (2011) and a host of others. Extant literature on young adults' bank selection revealed that when it comes to factors impinging on bank selection, parental influence and convenience hitherto used to be the most important influencing factors. Subsequent studies found out that convenience which used to include proximity to home or workplace has diminished in importance due to the emergence of technology-assisted services such as ATM, internet banking, credit cards, online shopping etc. Although convenience could still be valid, but the traditional definition of convenience is rendered invalid (Hinson et al. 2013). Sharma and Rao (2010) expressed a considered view that despite the promising nature of young customers, it has not been given enough attention, especially university students. It can be realised that following the 2008-2009 financial crisis 
customers to banks have become continuously fastidious and savvy in taking decisions about choice of banks based on trust and their banking service needs (KHaitbaeva et al. 2014).

Subsequently, Katrircioglu et al. (2011) investigated undergraduates' bank selection criteria who were considered the future potential customers to banks. Their study revealed that availability and convenient locations of ATM services, speed and quality of services and recommendations from parents and friends were the most critical factors determining both Turkish and non-Turkish undergraduates bank selection. They indicated that the introduction of technology in the service industry has a significant impact on the interaction between service providers and customers and companies are motivated to invest in technology to secure their longevity and relevance in this electronic age. This observation is relevant to make because social media has steadily emerged as the bedrock of recent technology and became the most preferred tool of communication of late (Hayta, 2013, Cakir et al. 2013, Dryer 2010).

According to Cakir et al. (2013), social media takes a special place in the lives of young consumers which should be a serious concern to financial service marketers and firms. It is not only indispensable to young customers, but unavoidable communication tool to every organisation and it is rapidly growing (Hayta 2013). Suffice to indicate that it took radio 30 years to reach 50 million listeners and 13 years for TV to reach 50 million viewers. As for social media, it strikingly reached 50 million users within a span of 4 years, and Facebook amazingly attained 50 million users in one and a half years (Hayta 2013). Studies by Haciefendioglu (2011) espoused that consumers, especially the youth, are influenced by the views of their friends on social media when they are making decisions to purchase and what they end up buying are guided by the opinions of friends.

Internet-based tools are becoming ubiquitous and pervasive among recent studies concerning youth bank selection. Chan et al. (2017) study on marketing bank service to youth in China discovered that banks in China could improve upon their competitive edge and brand reputation by upgrading the professionalism of their front-line staff. The banks can also achieve that by enhancing efficiency and transparency and streamlining the process of service acquisition and delivery. They concluded that in terms of efficacy in contacting the youth, the banks have to conduct that via offline and online promotional activities, including co-branding with popular online games. It is, however, emphasised that the banks in China are still glued to the traditional banking services as Western banks have done. Lelissa and Lelissa (2017) also conducted a study on crucial factors determining the choice of commercial banks in a banking environment that had the speed of service among the best in the industry with adequate branch network at vantage spots and forex resources easy to acquire at banks. The findings revealed that service quality and availability in addition to the quality and accessibility of physical and human resources came out as the most significant determinants of bank choice. The regression analysis further indicated that the aforementioned factors not only impact on customers' choice of banks but their loyalty levels to banks. To Maiyaki (2011), it is the size of a bank, its total assets, proximity and convenience of banks to office or residence, personal security of customers and 
ease of accounts openings to banks that are considered important to customers. This assertion sits well with Caratelli (2013) findings that before other factors come into play, customers initially look at the reputation of a bank and then move further to consider other factors such as technology, price and opinions of relations and friends. This postulation holds well for contexts where there are frequent banks failures and volatilities. For instance, this study conducted by Nkamnebe et al. (2014) reveals bank financial stability, availability and functional ATM network, family and friends' influences, the proximity of bank branches to the university, professional bank staff and internal and external aesthetics were the six most influencing factors in a ranked order. In the case of Nigeria, the financial stability of the bank came on top. The authors discussed that the frequency of bank failures in Nigeria before the consolidation of the banking sector could reasonably be responsible for the cause of apprehension among the Nigerian banking public.

It can be fathomed that opinions of family and friends classified as word of mouth (WOM) seem to be prominent in most of the findings. This makes WOM so important in bank selection criteria and has attracted further interrogation as evidenced in Almossawi's (2015) work which sought to assess the impact of WOM on bank selection decision of the youth. It is reported that the effectiveness of WOM as far as changing the attitudes of customers is a concern, as well as its influence on their purchasing decisions, exceeds that of advertising and direct sales. There is evidence of a strong and positive correlation between WOM and satisfaction with satisfied customers having an irresistible proclivity to relate positive WOM to others and the vice versa (Almossawi 2015). Dillon (2013) conducted similar studies in the Indian financial services sector and arrived at the results that most of the respondents regarded WOM as an effective means of communication in enrolling new customers and sustaining existing ones.

\section{Customer Loyalty Dimensions}

Customer loyalty building is a critical key factor in gaining market share and establishing a sustainable competitive advantage (Afsar et al. 2010). These researchers thought of loyalty to a bank as "continuing patronage over time" and that the degree of loyalty can be well gauged by monitoring the customer accounts within a specified space of time and observing the extent of "continuity in patronage". It is observed by experts that the financial sector has witnessed serious structural changes exposing the area to serious competition, slow development of basic demand and increased deregulation or if you like liberalisation of the banking sector. To stem this tide, many innovative and sophisticated means of gaining and retaining customers have emerged. This is because the importance of loyal customers cannot be relegated to the periphery in the sense that it costs several times much more to retain a customer than to scout for a new one. This brings to forth the necessity of designing programmes and strategies aimed at retaining loyalty with benchmarking and tracking customer satisfaction and loyalty been instrumental (Abdul Mumin et al. 2012).

It must be pointed out that maintaining a high rate of customer satisfaction does not necessarily deliver customer loyalty in that firms will still lose customers who change residence, retires or no longer need particular services. Yet, the 
contribution of satisfaction is still highly correlated to loyalty as noted by Afsare et al. (2010) that there are two types of loyal customers who are satisfied and unsatisfied. In demystifying this, he made the point that satisfaction is not a sine qua non to loyalty since satisfied customers may not be loyal. Unsatisfied customers incidentally, can be loyal as a result of attachment and commitment to a product/service. Conversely, satisfied customers for lack of commitment and attachment to a product/service may switch to better quality products/services once it is readily available. According to Dick and Basu (1994), loyalty is a complex construction constituting both psychological and behavioural divides. Loyalty of any form is anticipated to result in repeated purchases and favourable attitudes towards a firm. They contended that in defining customer loyalty, it should be considered both in terms of customer behaviour, which is tantamount to the retention and in terms of customer attitudes.

Filip and Anghel (2009) think that the determinants of loyalty can be viewed in terms of the positive and negative influencing factors on the customer-bank relationship. Said differently, there are some critical issues that impact on sustaining and improving relationships and others that mitigate customer behaviours and attitudes towards being retained and being loyal. Further, they categorised the factors that assist relationships into two with the first one been issues that impact on the customers willingness to participate in a relationship stemming from great satisfaction, better service quality, sense of trust and commitment to the bank, good bank image, and ancillary benefits that project good value of the core products and services. The second is postulated to be those issues limiting the customer from sustaining the relationship and bond issues that will not allow switching. They enumerated issues such as a legal bond (contractual arrangements), economic bonds (financial penalties or the loss of some monetary rewards), cost of searching information and evaluation, learning cost, uncertainty cost, small number of attractive alternatives in the market, and also geographic bonds (there is no other bank in the geographical location of the customer) as some of the limiting barricades to exit.

Clark (2007) has a conviction that customer loyalty is generally endorsed as worth nurturing and outlined six significant factors to be impinging on loyalty and commitment to be core offerings, satisfaction, elasticity level, the market place, demographics and share of wallet. He asserted that firms that boast of very high loyal customers achieved that not on card programmes or gimmicks but by reliable, dependable core offerings that sink well with the customers. He also considered good level of satisfaction to be essential in creating loyal customers but not a good measure of the level of loyalty, explaining why the customer can still defect or switch despite being satisfied. Elasticity, in his submission is described to be the significance and strength of a purchasing decision and that the importance of the product or service will determine the level of involvement. The market place also determines the level of loyalty as the opportunity to switch will be spelt out in the market. They could be inertia loyalty where it is difficult and time-consuming to switch to a new bank. He also mentions demographics to refer to the different segments in the market and share of wallet as a factor creating the impression that 
it is more beneficial or profitable to increase what the customer spend on the bank than acquiring a new one.

Narteh and Kuada (2014) found out that like Western countries, the Ghanaian banks' customers share significant importance to relational, core, and tangible dimensions of banking services. Relational factors were discovered to be the most important determinant of customer satisfaction followed by the individualised attention given to customers, the courtesy and consistency of the interaction process and content all realised to have great impact on customer satisfaction. This revelation is significant because research postulates that the ability of retail banks to make their customers satisfied is instrumental to their long-term business success and satisfied customers turn to be loyal to their banks.

\section{Theoretical Underpinning}

Customer's preference is viewed in marketing as the likelihood to select one thing over others. Customers' preference is regarded in economics as the taste of the individual, which is measured by the utility of different bundle of goods or services (Sowunmi et al. 2014, Thiyagaraj 2015). In the field of psychology, preference is considered as an individual attitude and predisposition towards a defined object that stimulate or determines the person's behaviour in the decisionmaking stage (Aregbeyen 2011). The decision here is a choice that could be simple or complex, and the process involves customers collecting relevant information that concerns the attributes of products or firms. The gathered information is exquisitely evaluated based on their likes or preferences. The rational choice theory and competition theory elucidate that the more as follows.

\section{Rational Choice Theory and Competition Theory}

The rational choice theory provides useful insights on the choice or selection behaviour of the individual customer, while the competition theory explains how firms try to win customers patronage and loyalty through service excellence, meeting customers' needs and providing innovative products (Russo \& Confente 2017, Baines et al. 2017). The choice theory, otherwise referred to as rational choice theory or rational action theory, is a framework for understanding and often formally modelling social and economic behaviour. Rationality expresses the idea of wanting more rather than less of a good, is widely used as an assumption of the behaviour of individuals in microeconomic models. The theory posits that patterns of behaviour in societies reflect the choices made by individuals as they try to maximise their benefits and minimize their costs (Smith 2017). In other words, people make decisions about how they should act by comparing the costs and benefits of different courses of action.

Consequently, patterns of behaviour develop within the societies that result from those choices (Smith 2017). Rational decision making entails choosing an action given one's preferences, the actions one could take, and expectations about the outcomes of those actions (Morton 2017). The validity of rational decision making is rooted in two complementary assumptions, namely completeness and 
transitivity. Completeness requires that all actions of the individual can be ranked in an order of preference (indifference between two or more is possible), while transitivity is a condition that if choice $A$ is preferred to $B$, and action $B$ is preferred to $C$, then $A$ is preferred to $C$. Together these assumptions form the result that given a set of exhaustive and exclusive actions to choose from, an individual can rank them in terms of his preferences and that his preferences are consistent.

Competition in economics is best described as the existence within a market for some good or service of a sufficient number of buyers and sellers such that no single market participant has enough influence to determine the going price of the good or service. Competition occurs when two or more organisations act independently to supply their products to the same group of consumers. Direct competition exists where organisations produce similar products that appeal to the same group of consumers. Indirect competition exists when different firms make or sell items which, although not in head to head competition, still compete for the same money in the customers' pocket. Both direct and indirect competition cause commercial firms to develop new products, services and technologies which would give consumers greater selection and better products. The greater selection typically causes lower prices for the products, compared to what the price would be if there were no competition (monopoly) or little competition (oligopoly). Thus, the competitive strategy of firms is dependent upon consumers' choice characteristics which tend to influence firms productive decision towards the satisfaction of consumers preferences.

\section{The Methodology of the Study}

The study adopted a quantitative approach since the purpose of this paper is to examine young adults' selection and loyalty to banks in Ghana. The target population were $1^{\text {st }}$ year university students who mostly are opening/operating bank accounts for the $1^{\text {st }}$ time on their own. A survey was done using questionnaires among students at the University of Ghana. The questionnaires were distributed, before and after lectures, and administered. Three hundred and seventy (370) questionnaires were distributed, and three hundred and twenty (320) were answered and retrieved, however, only two hundred and thirty (230) of the questionnaires were used for further analysis representing $62 \%$. This high response rate was due to the authors' strategy of handing over questionnaires and staying around for respondents to fill and hand them back as far as possible. Such a high rate of response is considered satisfactorily adequate for statistical reliability and generalizability. The two hundred and thirty (230) emerged as complete and worthy of analysis after we went through the cleaning process.

The authors formulated structured questionnaires for application in the survey. The questionnaires were formulated out of the concepts that were raised in the review of the literature. The questionnaires were put into three sections. Thus, section A, B, and C. Section "A" captured questions on the basic demographics of the respondents. Section "B" also captured questions on bank selection, and section " $C$ " captured questions on bank loyalty decisions of young adult Ghanaians. The questions were measured on a five-point Likert-type scale of importance 
ranging from 1 (least important) to 5 (very important). The list, as indicated previously was derived from similar studies, including Gerrard and Cunningham (2001), Almossawi (2001), Thwaites and Vere (1995) and a host of others.

The participants were undertaking studies in about five different faculties. The authors have employed non-probability convenience sampling in the study. Convenience sampling is a non-probability sampling method in which samples are drawn at the convenience of the researcher (Kuada 2012). It is established on the assumption that the target population is homogeneous and the individuals selected are similar to the overall target population with regards to the characteristics studied (Hair et al. 2006: 340). The research questionnaires had a standard set of instructions as part of the cover letter for the respondents, informing them of the purpose of the study and how to respond to the questions and motivating them to participate in the study. The authors commune from faculty to faculty, library to students' group rooms to get students to solicit for their participation. The data were entered into SPSS (version 21) for descriptive and factor analysis in attempts to reduce the data collected (Narteh and Owusu-Frimpong 2011). The factor analysis was executed using varimax rotation on the responses to the bank selection statements and loyalty decisions statements (Hinson et al. 2017).

\section{Results of the Study}

In the extant literature on the financial services sector, age and gender are the common demographic variables investigated (Narteh and Owusu-Frimpong 2011). Therefore, this investigation included these demographic features with a programme of study and area of study to understand the bank selection and loyalty decisions in Ghana. The majority of the respondents were studying undergraduate business-related discipline. Also, majority of the respondents were males and below 20 years. Table 1 details the respondent demographic information.

Table 1. Respondent Descriptive Information

\begin{tabular}{|l|c|c|c|}
\hline Profile & Indicators & Frequency & Percentage \\
\hline \multirow{3}{*}{ Gender } & Male & 177 & 77 \\
\cline { 2 - 4 } & Female & 53 & 23 \\
\cline { 2 - 4 } & Total & 230 & 100 \\
\hline \multirow{3}{*}{ Program of Study } & Below 20 years & 144 & 62.6 \\
\cline { 2 - 4 } & $20-30$ Years & 86 & 37.4 \\
\cline { 2 - 4 } & Total & 230 & 100 \\
\cline { 2 - 4 } & Undergraduate & 191 & 83 \\
\cline { 2 - 4 } & Masters & 39 & 17 \\
\hline \multirow{3}{*}{ Area of Study } & Total & 230 & 100 \\
\cline { 2 - 4 } & Business Related & 176 & 76.5 \\
\cline { 2 - 4 } & Non-Business Related & 54 & 23.5 \\
\hline
\end{tabular}

Source: Field Data

This study aimed to identify the factors influencing Ghanaian youth bank selection in light of increasing competition. Similarly, the study also sought to 
establish bank loyalty decisions. Existing scales on factors measuring bank selection was used, the mean and standard deviations recorded are presented on Table 2. While Table 3 presents the means and standard deviations on bank loyalty measures. The least mean was 3.63 in respect of bank's providing assurance for customers while the least standard deviations were 0.566 in respect of a bank having responsive staff. All the remaining items recorded higher means (above 3.63) and higher standard deviations (above 0.566). Accordingly, factor analysis was executed. The determinants of bank selection and client loyalty decisions are presented on Table 4 and 6 (internal consistency and related decision on bank selection) and Table 5 and 7 (internal consistency and related decision on bank loyalty decisions).

Table 2. Bank Selection Indicators

\begin{tabular}{|l|c|c|c|}
\hline Items & N & Mean & $\begin{array}{c}\text { Std. } \\
\text { Deviation }\end{array}$ \\
\hline Responsive staff & 230 & 4.27 & .566 \\
\hline Customer services with regulation & 230 & 4.26 & .669 \\
\hline Bank image & 230 & 4.16 & .696 \\
\hline Bank promotions & 230 & 4.16 & .570 \\
\hline Bank advertisement & 230 & 4.15 & .604 \\
\hline Endorsements by University Authority & 230 & 4.14 & .723 \\
\hline Bank regulations & 230 & 4.12 & .861 \\
\hline Use multiple banks for Varied transactions & 230 & 4.11 & .757 \\
\hline Reliable services & 230 & 4.10 & .620 \\
\hline Cost of bank transactions & 230 & 4.10 & .890 \\
\hline Competence of a bank's staff & 230 & 4.09 & .655 \\
\hline Family recommendations & 230 & 4.08 & .720 \\
\hline Easier account opening & 230 & 4.07 & .670 \\
\hline Competence of bank staffs & 230 & 4.07 & .683 \\
\hline Free Banking (No Bank charges) & 230 & 4.07 & .680 \\
\hline Staff capabilities & 230 & 4.02 & .721 \\
\hline Ample variety of products & 230 & 4.02 & .705 \\
\hline Bank promises & 230 & 4.01 & .647 \\
\hline Empathetic staffs & 230 & 4.00 & .825 \\
\hline Less restrictions on operations & 230 & 3.99 & .745 \\
\hline A well-established bank & 230 & 3.97 & .693 \\
\hline Service offers of a Bank & 230 & 3.97 & .667 \\
\hline Knowledgeable staff & 230 & 3.97 & .711 \\
\hline Brand endorsements & 230 & 3.95 & .780 \\
\hline Banking halls & 230 & 3.93 & .833 \\
\hline Bank friendliness & 230 & 3.90 & .806 \\
\hline Availability of ATMs & 230 & 3.90 & .905 \\
\hline Convenient locations & 230 & 3.88 & .800 \\
\hline Fulfils its promises & 230 & 3.81 & .824 \\
\hline Recommendation by Peers & 230 & 3.77 & .913 \\
\hline Bank charges & 230 & 3.71 & .929 \\
\hline Provides assurance & 230 & 3.63 & .758 \\
\hline Soure & & & \\
\hline
\end{tabular}

Source: Field Data 
Table 3. Bank Loyalty Measures

\begin{tabular}{|l|c|c|c|}
\hline Items & N & Mean & $\begin{array}{c}\text { Std. } \\
\text { Deviation }\end{array}$ \\
\hline Friendly Bank & 230 & 4.08 & .797 \\
\hline Staff assurance & 230 & 3.98 & .736 \\
\hline Bank image & 230 & 3.95 & .813 \\
\hline Well established bank & 230 & 3.85 & .851 \\
\hline Bank reputation & 230 & 3.83 & .913 \\
\hline ATM service satisfaction & 230 & 3.81 & 1.101 \\
\hline Satisfaction & 230 & 3.80 & .826 \\
\hline Reliability of a bank & 230 & 3.78 & .988 \\
\hline Many regulations & 230 & 3.78 & .996 \\
\hline Responsiveness of a bank & 230 & 3.76 & .873 \\
\hline Empathetic behaviour of a bank staff & 230 & 3.75 & 1.000 \\
\hline Unexplained charges & 230 & 3.75 & .960 \\
\hline Unnecessary bank charges & 230 & 3.73 & .997 \\
\hline Low charges & 230 & 3.70 & 1.012 \\
\hline Process satisfaction & 230 & 3.69 & 1.048 \\
\hline Several procedures & 230 & 3.68 & 1.002 \\
\hline Trusted bank & 230 & 3.64 & .996 \\
\hline Commitment to promises & 230 & 3.63 & 1.022 \\
\hline Bank operating procedures & 230 & 3.63 & 1.116 \\
\hline Happiness & 230 & 3.62 & .949 \\
\hline Bank charges & 230 & 3.62 & 1.032 \\
\hline Explained regulatory requirements & 230 & 3.56 & 1.042 \\
\hline Relationship marketing practices & 230 & 3.49 & 1.064 \\
\hline Bank communication & 230 & 3.40 & 1.101 \\
\hline Souce: Fid Dat & & & \\
\hline
\end{tabular}

Source: Field Data

\section{Factor Analysis}

Table 4, 5, 6 and 7 present the results of exploratory factor analysis for bank selection and bank loyalty measures. The Bartlett test of sphericity for bank selection (Approximate Chi-Square, 5,296, df. 528, Sig. 0.000) and that of bank loyalty, (Approximate Chi-Square, 1913, df. 276, Sig. 0.000) and the KMO measure of sampling adequacy for bank selection was a value of 0.860 and that bank loyalty had a value of 0.760 . These outcomes confirm that there were significant correlations among the variables to warrant the application of factor analysis (Narteh and Owusu-Frimpong 2011). Guided by previous studies, only factors with eigenvalues equal to or greater than only factor loadings with a minimum of the threshold of 0.5 (Hair et al. 2008, Malhotra and Birks 2008).

Table 4 provides six (6) factor from the thirty-four (34) items. Their communalities, Eigen value, per cent of variance and per cent are showed. The six factors together have a percentage of about 63. Factor 1 was named Bank Service/ Convenience due to the high number of bank service features like available ATMs, variety of products, convenient locations, use of multiple branches, staff 
Vol. 7, No. $2 \quad$ Ibrahim et al.: Revisiting Young Customers' Bank Selection and Loyalty...

competence, and endorsement by the university authority. Factor 1 accounted for about fourteen (14) per cent of the variance.

Table 4. Principal Component Analysis of Bank Selection Measures

\begin{tabular}{|c|c|c|c|c|c|}
\hline Variable Cumulative & Communality & Factor & $\begin{array}{l}\text { Eigen } \\
\text { Value }\end{array}$ & $\begin{array}{c}\text { Per cent } \\
\text { of } \\
\text { Variance }\end{array}$ & $\begin{array}{l}\text { Per } \\
\text { cent }\end{array}$ \\
\hline Reliable services & .571 & 1 & 4.63 & 14.02 & 14.02 \\
\hline Responsive staff & .495 & 2 & 4.44 & 13.47 & 27.49 \\
\hline Good banking halls & .602 & 3 & 4.40 & 13.33 & 40.81 \\
\hline Empathetic staffs & .559 & 4 & 2.67 & 8.08 & 48.89 \\
\hline Provides assurance & .648 & 5 & 2.50 & 7.57 & 56.46 \\
\hline A well-established bank & .550 & 6 & 2.04 & 6.19 & 62.65 \\
\hline Bank image & .493 & & & & \\
\hline Fulfils its promises & .603 & & & & \\
\hline Bank friendliness & .645 & & & & \\
\hline Easier account opening & .582 & & & & \\
\hline $\begin{array}{l}\text { Fewer restrictions on } \\
\text { operations }\end{array}$ & .640 & & & & \\
\hline $\begin{array}{l}\text { Customer services with } \\
\text { regulation }\end{array}$ & .631 & & & & \\
\hline Bank regulations & .600 & & & & \\
\hline Bank advertisement & .677 & & & & \\
\hline Service offers of a Bank & .700 & & & & \\
\hline Bank promotions & .641 & & & & \\
\hline Bank promises & .778 & & & & \\
\hline Competence of bank staff & .681 & & & & \\
\hline Knowledgeable staff & .824 & & & & \\
\hline Staff capabilities & .804 & & & & \\
\hline Competence of bank staffs & .838 & & & & \\
\hline Peer recommendation & .898 & & & & \\
\hline $\begin{array}{l}\text { Endorsements by University } \\
\text { Authority }\end{array}$ & .723 & & & & \\
\hline Brand endorsements & .760 & & & & \\
\hline Family recommendations & .814 & & & & \\
\hline $\begin{array}{l}\text { Free Banking (No Bank } \\
\text { charges) }\end{array}$ & .822 & & & & \\
\hline Bank charges & .908 & & & & \\
\hline $\begin{array}{l}\text { Use multiple banks for varied } \\
\text { transactions }\end{array}$ & .747 & & & & \\
\hline Cost of bank transactions & .697 & & & & \\
\hline Convenient locations & .626 & & & & \\
\hline Availability of ATMs & .662 & & & & \\
\hline Ample variety of products & .642 & & & & \\
\hline Number of branches & .523 & & & & \\
\hline
\end{tabular}

Source: Field Data 
Table 5. Internal Consistency and Related Decision on Bank Selection

\begin{tabular}{|c|c|c|c|c|}
\hline Factor and Items & Loadings & $\begin{array}{c}\text { Item-total } \\
\text { correlation }\end{array}$ & Reliability & Decision \\
\hline $\begin{array}{l}\text { Factor 1: Bank Service/ } \\
\text { Convenience }\end{array}$ & & & .884 & Retained \\
\hline Competence of a bank's staff & .735 & .734 & & \\
\hline $\begin{array}{l}\text { Endorsements by University } \\
\text { Authority }\end{array}$ & .684 & .739 & & \\
\hline $\begin{array}{l}\text { Use multiple banks for different } \\
\text { transactions }\end{array}$ & 685 & .731 & & \\
\hline Cost of bank transactions & .647 & .710 & & \\
\hline Convenient locations & .711 & .607 & & \\
\hline Availability of ATMs & .678 & .642 & & \\
\hline Variety of products & .647 & .601 & & \\
\hline $\begin{array}{l}\text { Factor 2: Service Quality/ } \\
\text { Bank Image }\end{array}$ & & & .857 & Retained \\
\hline Good banking halls & .513 & .550 & & \\
\hline Empathetic staffs & .598 & .545 & & \\
\hline Gives me assurance & .801 & .624 & & \\
\hline A well-established bank & .597 & .623 & & \\
\hline Based on its image & .501 & .502 & & \\
\hline Fulfils its promises & .592 & .506 & & \\
\hline Friendly bank & .633 & .674 & & \\
\hline Less restrictions on operations & .580 & .544 & & \\
\hline Service offers & .793 & .702 & & \\
\hline $\begin{array}{l}\text { Factor 3: Staff Attitude/ } \\
\text { Recommendation }\end{array}$ & & & .911 & Retained \\
\hline Bank promises & .586 & .682 & & \\
\hline Knowledgeable staff & .825 & .789 & & \\
\hline Staff have good capabilities & .817 & .827 & & \\
\hline Brand endorsements & .777 & .764 & & \\
\hline Family recommendations & .808 & .812 & & \\
\hline $\begin{array}{l}\text { Factor 4: Core Service/ } \\
\text { Communication }\end{array}$ & & & .703 & Retained \\
\hline Reliable services & .706 & .498 & & \\
\hline Responsive staff & .635 & .434 & & \\
\hline Regulations governing bank & .597 & .481 & & \\
\hline Bank advertisement & .619 & .598 & & \\
\hline Factor 5: & & & .944 & Delete \\
\hline Recommendation by Peers & .892 & .894 & & \\
\hline Bank charges & .902 & .894 & & \\
\hline Factor 6: Customer Service & & & .607 & Retained \\
\hline Easier account opening & .628 & .395 & & \\
\hline Good customer services & .760 & .381 & & \\
\hline Bank promotions & .604 & .482 & & \\
\hline
\end{tabular}

Source: Field Data

Factor 2 was named Service quality/Bank image, items like having good looking banking halls, empathetic staff, delivering of service assurance, fewer 
restrictions of operations. Factor 2 accounted for about thirteen (13) per cent of the variance. Factor 3 was named Staff attitude/recommendation as it comprised items like knowledgeable staff, staff with good capabilities, bank promise delivery, brand endorsement and family recommendation. Factor 3 accounted for about thirteen (13) per cent of the variance. Factor 4 was named core service/ communication as it included: reliable service, responsive service, bank regulatory regime and bank advertisement. Factor 4 accounted for about eight (8) per cent of the variance. Factor 5 was eliminated for conceptual and theoretical weaknesses. Factor 5 accounted for about eight (8) per cent of the variance. Factor 6 was named customer service because it included items like good customer service, easier account opening and bank promotions. Factor 6 accounted for about six (6) per cent of the variance.

Table 6. Principal Component Analysis of Bank Loyalty Measures

\begin{tabular}{|l|c|c|c|c|c|}
\hline Variable Cumulative & Communality & Factor & $\begin{array}{c}\text { Eigen } \\
\text { Value }\end{array}$ & $\begin{array}{c}\text { Per cent } \\
\text { of } \\
\text { Variance }\end{array}$ & $\begin{array}{c}\text { Per } \\
\text { cent }\end{array}$ \\
\hline Bank's image & .713 & 1 & 3.11 & 12.94 & 12.94 \\
\hline Bank's reputation & .620 & 2 & 3.02 & 12.56 & 25.50 \\
\hline Well established Bank & .612 & 3 & 2.24 & 9.34 & 34.65 \\
\hline Friendly Bank & .581 & 4 & 2.16 & 9.00 & 43.84 \\
\hline Responsiveness of a bank & .675 & 5 & 2.08 & 8.64 & 52.48 \\
\hline Reliability of a bank & .662 & 6 & 1.60 & 6.66 & 59.15 \\
\hline Empathetic behaviour of a bank & .685 & 7 & 1.10 & 4.60 & 63.74 \\
\hline Staff assurance & .633 & & & & \\
\hline Satisfaction & .741 & & & & \\
\hline Process satisfaction & .691 & & & & \\
\hline ATM service satisfaction & .668 & & & & \\
\hline Happiness & .468 & & & & \\
\hline Bank charges & .637 & & & & \\
\hline Unnecessary bank charges & .590 & & & & \\
\hline Unexplained bank charges & .621 & & & & \\
\hline Low charges & .712 & & & & \\
\hline Commitment to promises & .638 & & & & \\
\hline Trusted bank & .625 & & & & \\
\hline Bank communication & .647 & & & & \\
\hline Relationship marketing practices & .641 & & & & \\
\hline Bank operating procedures & .575 & & & & \\
\hline Several procedures & .560 & & & & \\
\hline Many regulations & .614 & & & & \\
\hline $\begin{array}{l}\text { Explained regulatory } \\
\text { requirements }\end{array}$ & .690 & & & & \\
\hline Souc: & & & & & \\
\hline
\end{tabular}

Source: Field Data 
Table 7. Internal Consistency and Related Decision on Bank Loyalty Measures

\begin{tabular}{|c|c|c|c|c|}
\hline Factor and Items & Loadings & $\begin{array}{l}\text { Item-total } \\
\text { correlation }\end{array}$ & Reliability & Decision \\
\hline $\begin{array}{l}\text { Factor 1: Friendly } \\
\text { Operations / Regualtions }\end{array}$ & & & .748 & Retained \\
\hline Makes me happy & .553 & .464 & & \\
\hline Trusted bank & .668 & .501 & & \\
\hline Operating procedures & .579 & .518 & & \\
\hline Bank procedures & .656 & .566 & & \\
\hline Regulations & .751 & .519 & & \\
\hline $\begin{array}{l}\text { Factor 2: Relationship } \\
\text { Management }\end{array}$ & & & .799 & Retained \\
\hline Education & .753 & .483 & & \\
\hline Communication & .717 & .647 & & \\
\hline $\begin{array}{l}\text { Relationship marketing } \\
\text { practices }\end{array}$ & .769 & .639 & & \\
\hline Satisfaction & .753 & .686 & & \\
\hline $\begin{array}{l}\text { Factor 3: Service Quality / } \\
\text { Financial benefits }\end{array}$ & & & .721 & Retained \\
\hline Reliability of a bank & .583 & .558 & & \\
\hline $\begin{array}{l}\text { Empathetic behaviour of a } \\
\text { bank }\end{array}$ & .660 & .355 & & \\
\hline Bank charges & .647 & .552 & & \\
\hline Unnecessary bank charges & .662 & .392 & & \\
\hline Low charges & .536 & .550 & & \\
\hline $\begin{array}{l}\text { Factor 4: Client } \\
\text { Satisfaction }\end{array}$ & & & .700 & Retained \\
\hline Responsiveness of a bank & .799 & .567 & & \\
\hline Satisfaction & .822 & .550 & & \\
\hline Committed to promises & .568 & .451 & & \\
\hline Factor 5: Bank Image & & & .595 & Retained \\
\hline Bank's image & .748 & .424 & & \\
\hline A well established & .755 & .424 & & \\
\hline Factor 6 & & & .539 & Delete \\
\hline Bank reputation & .702 & .375 & & \\
\hline ATM service satisfaction & .625 & .375 & & \\
\hline Factor 7 & & & & Delete \\
\hline Friendly bank & .830 & & & \\
\hline
\end{tabular}

Source: Field Data

Table 6 and 7 provides seven (7) factors from the twenty-four (24) items. Their communalities, Eigen value, per cent of variance and per cent are showed. The seven (7) factors together had a percentage of about sixty-four per cent (64\%). Factor 1 was named Friendly Operations/Regulations dues to the high number of operational descriptors like regulations, trusted bank, makes me happy, operating procedures. The factor 1 accounted for about thirteen (13) percent of the variance. Factor 2 was named Relationship management due to it loading items like: service education, service communication, and relationship marketing practices. The 
factor 2 accounted for about thirteen (13) percent of the variance. The factor 3 was named Service quality/financial benefits as it loaded items like: reliability of a bank, empathetic behaviour of a bank, bank charges, unnecessary charges, and low charges. The factor 3 accounted for about nine (9) percent of the variance. The factor 4 was named client satisfaction because it loaded items like: responsiveness of a bank, satisfaction, commitment to promises. The factor 4 accounted for about nine (9) percent of the variance. The factor 5 was named Bank Image as it loaded items on bank image. The factor 5 accounted for about nine (9) percent of the variance. The factor 6 and 7 were eliminated for conceptual and theoretical weaknesses. The factor 6 accounted for about seven (7) per cent and 7 accounted for about five (5) per cent of the variance.

Implicit in the study findings on Tables 5 and 7 is an ordering of importance using the eigenvalues or per cent of the variance. On Table 5, Bank service/ convenience is the most important factor in youth bank selection, followed by service quality/bank image, then staff attitude/recommendation, the core service/ communication and customer service come next respectfully. As such, bank managers in an attempt to attract youth customers should leverage on these factors. Similarly, youth loyalty to bank factors is ranked on table VII. Friendly operations/regulations were identified as the most important factor influencing youth loyalty to banks. The relationship management strategy was found to be the next most important factor. Service quality / financial benefits, client satisfaction and bank image, were respectfully identified as influencers of youth loyalty to a bank.

\section{Discussion of Study Findings}

The youth bank choice and loyalty decisions are very crucial in today's competitive landscape. Due to concepts like customer life time value, most banks are today scouting for young customers. In Ghana, $1^{\text {st }}$ year students are frequently besieged by banks trying to convince them to open bank accounts with them. Therefore, a study on what informs the youth on selecting banks is timely. The study found that bank service/convenience, service quality/bank image, staff attitude/recommendation, core service/communication, and customer service were identified as factors that could affect youth decisions about banks in Ghana. These findings have some similarities with existing bank selection examinations (Almossawi 2001), however, the peculiarity of this study occasioned the variations of the study findings. Almossawi's (2001) study was equally on youth customers in the Gulf region. The context and time variations may be the result of the variation in study findings. More so, the study findings might be due to the hard to differentiate banking service. According to Hinson et al. (2006), there is no difference in the service provisions of banks in Ghana. Thus, banks in Ghana provide virtually similar or the same services. As such, for the youth to select a bank, the bank's service must be outstanding or considered different from the existing alternatives. The cost of bank transactions (bank service) was equally 
advanced by Phuong et al. (2000) to influence youth bank selections. The image of a bank affects the youth in their choice of a bank (Sayani and Miniaoui 2013).

Similarly, the study found that: friendly operations/regulations, relationship management, service quality/financial benefits, client satisfaction, and bank image were responsible for youth staying with a bank. Friendly operations or regulations were identified to have the strongest influence on youth decisions to stay with a bank. This included a bank's day to day procedures of how to deposit or withdraw money from an account. In addition, relationship management was also key in this study. Thus, banks should continue to implement and practice relationship management. Relationship marketing or management is a key determinant of customer loyalty behaviours (Ndubisi et al. 2008). According to Amin et al. (2013), there is an association between image and client loyalty. In view of that, the bank image could inform a youth decision to stay with a bank. More so, satisfaction was also identified to have a relationship with loyalty (Fraering and Minor, 2013). According to Osayawe Ehigie (2006), service quality predicts a client's loyalty. Thus, the perceive service quality levels of a bank could influence a youth on his/her decisions to stay with a bank.

\section{Conclusions and Study Implications}

The goal of this paper was to identify the crucial factors influencing youth bank selection in Ghana and equally provide the factors that might help banks keep their customers. Consequently, factors such as bank service/convenience, service quality/bank image, staff attitude/recommendation, core service/ communication, and customer service were identified as factors that could affect youth decisions about banks in Ghana. Similarly, the study found that: friendly operations, relationship marketing, service quality, client satisfaction, and bank image were responsible for youth staying with a bank. The contribution of this investigation could be viewed via both theoretical and practical implications. From a theory standpoint, the study explores the bank selection indicators from a developing economy perspective using young consumers. The study's respondents were made of first-time bankers, explaining why some of the traditional constructs of bank selection like technology-enabled services might not have loaded. Accordingly, this study will undoubtedly contribute to the existing literature on bank selection. The practical implications of this investigation are the provision in a rank manner, factors that influence youth bank selection and loyalty decisions. Bank managers are encouraged to consider the positions of each factor in developing strategic directions. Findings from this study showed that young customers placed more emphasis on a bank's services/convenience, service quality/bank image, staff attitude/recommendation, core service/communication, and customer service. Therefore, banks, in their attempts to attract young customers, could develop strategies leveraging on those factors. Similarly, the youth customer segment will continue to do business with a bank if the bank has: friendly operations/regulations, relationship marketing, service quality/financial 
benefits, client satisfaction, and bank image among other things. Subsequently, bank loyalty strategic development could be designed to incorporate these factors.

\section{Limitations}

The findings of the study should painstakingly be interpreted in that the context of the study was narrowed to only first-year students of the University of Ghana, Legon. In light of this, generalising the findings beyond the context without caution may not be scholarly. Again, due to the limited time and resources, this study could not cover the different segments of the young population across the length and breadth of Ghana. In connection with this, future studies should consider revisiting the factors impinging on young adults' bank selection and loyalty decisions broadly across Ghana while paying particular emphasis on the role of technology and social media.

\section{Reference}

Abdul Mumin Y, Nkegbe, PK and Kuunibe N (2012) Analysis of customers' loyalty to Banks in Ghana. Research Journal of Finance and Accounting ISSN 2222-1697, Vol. 3, No.8

Abdul Mumin Y, Nkegbe, PK and Kuunibe N (2012) Analysis of customers' loyalty to Banks in Ghana. Research Journal of Finance and Accounting ISSN 2222-1697, Vol. 3, No.8.

African Development Bank (2016) Catalysing youth opportunity across Africa: www.afdb.org/fileadmin/uploads/afdb/Images/high_5s/Job_youth_Africa_Job_youth _Africa.pdf

African Development Bank (2016) Catalysing youth opportunity across Africa: www.afdb.org/fileadmin/uploads/afdb/Images/high_5s/Job_youth_Africa_Job_youth _Africa.pdf

Afsar B, Ur Rehman Z, Qureshi JA and Shahjehan, A. (2010). Determinants of Customer Loyalty in the Banking Sector: The case of Pakistan. African Journal of Business Management Vol. 4 (6) pp. 1040-1047

Afsar B, Ur Rehman Z, Qureshi JA and Shahjehan, A. (2010). Determinants of Customer Loyalty in the Banking Sector: The case of Pakistan. African Journal of Business Management Vol. 4 (6) pp. 1040-1047.

Almossawi M (2001) Bank selection criteria employed by college students in Bahrain: an empirical analysis. International Journal of Bank Marketing, 19 (3), 115-125.

Almossawi M (2001) Bank selection criteria employed by college students in Bahrain: an empirical analysis. International Journal of Bank Marketing, 19 (3), 115-125.

Almossawi MM (2015) Impact of word of mouth (WOM) on the bank selection decision of the youth: A case of Bahrain. International Journal of Business Management Vol.10, No. 4. ISSN 1833-3850

Almossawi MM (2015) Impact of word of mouth (WOM) on the bank selection decision of the youth: A case of Bahrain. International Journal of Business Management Vol.10, No. 4. ISSN 1833-3850. 
Amin M, Isa Z and Fontaine R (2013) Islamic banks: Contrasting the drivers of customer satisfaction on image, trust, and loyalty of Muslim and non-Muslim customers in Malaysia. International Journal of Bank Marketing, 31(2), 79-97.

Amin M, Isa Z and Fontaine R (2013) Islamic banks: Contrasting the drivers of customer satisfaction on image, trust, and loyalty of Muslim and non-Muslim customers in Malaysia. International Journal of Bank Marketing, 31(2), 79-97.

Aregbeyen O (2011) The determinants of bank selection choices by customers: Recent and extensive evidence from Nigeria International Journal of Business and Social Science Vol. 2, No. 22.

Aregbeyen O (2011) The determinants of bank selection choices by customers: Recent and extensive evidence from Nigeria International Journal of Business and Social Science Vol. 2, No. 22

Baines P Fill C Rosengren S and Antonetti P (2017) Fundamentals of Marketing. Oxford University Press.

Baines P Fill C Rosengren S and Antonetti P (2017) Fundamentals of Marketing. Oxford University Press.

Cakir F Cakir M and Eru O (2013) The effects of the social media on young consumers' consumption expenditure Journal of Social Sciences and Humanity Studies Vol. 5, No. 2 ISSN: 1309-8063

Cakir F Cakir M and Eru O (2013) The effects of the social media on young consumers' consumption expenditure Journal of Social Sciences and Humanity Studies Vol. 5, No. 2 ISSN: 1309-8063.

Chan K Tsang L and Chen J (2017) Marketing bank services to youth in China, Young Consumers, HKBU Staff Publication 18(3), 278-289.

Chan K Tsang L and Chen J (2017) Marketing bank services to youth in China, Young Consumers, HKBU Staff Publication 18(3), 278-289.

Clark P (2007) The loyalty guide. The wise marketer.

Clark P (2007) The loyalty guide. The wise marketer.

Cummins J D Rubio-Misas M and Vencappa D (2017) Competition, efficiency and soundness in European life insurance markets. Journal of Financial Stability, 28, 6678.

Cummins J D Rubio-Misas M and Vencappa D (2017) Competition, efficiency and soundness in European life insurance markets. Journal of Financial Stability, 28, 6678.

Dick AS and Basu K (1994) Customer loyalty: towards an integrated conceptual framework. Journal of the Academy of Marketing Science 22 (2) pp. 99-113. DOI: 10.1177/0092070314222001.

Dick AS and Basu K (1994) Customer loyalty: towards an integrated conceptual framework. Journal of the Academy of Marketing Science 22 (2) pp. 99-113. DOI: $10.1177 / 0092070314222001$

Dillon J (2013) Understanding word of mouth (WOM) communication: A case study of banking sector in India. Journal of Business and Management 9(3), 64-72.

Dillon J (2013) Understanding word of mouth (WOM) communication: A case study of banking sector in India. Journal of Business and Management 9(3), 64-72.

Dryer RL (2010) Advising Your Clients (and You!) in the New World of Social Media: What Every Lawyer Should Know About Twitter, Facebook, Youtube, \& Wikis, Utah Bar Journal, 3(23):16-21.

Dryer RL (2010) Advising Your Clients (and You!) in the New World of Social Media: What Every Lawyer Should Know About Twitter, Facebook, Youtube, \& Wikis, Utah Bar Journal, 3(23):16-21. 
Filip A and Anghel LD. (2009) Customer loyalty and its determinants in banking service environment Amtiteatru Economic. Vol XI, Nr. 26

Filip A and Anghel LD. (2009) Customer loyalty and its determinants in banking service environment Amtiteatru Economic. Vol XI, Nr. 26.

Fraering M and S Minor M (2013) Beyond loyalty: customer satisfaction, loyalty, and fortitude. Journal of Services Marketing, 27(4), 334-344.

Fraering M and S Minor M (2013) Beyond loyalty: customer satisfaction, loyalty, and fortitude. Journal of Services Marketing, 27(4), 334-344.

Haciefendioğlu Ş (2011) Reklam Ortamı Olarak Sosyal Paylaşım Siteleri ve Bir Araştırma, Bilgi Ekonomisi ve Yönetimi Dergisi, 11 (1):107- 115.

Hacıefendioğlu Ş (2011) Reklam Ortamı Olarak Sosyal Paylaşım Siteleri ve Bir Araştırma, Bilgi Ekonomisi ve Yönetimi Dergisi, 11 (1):107- 115.

Hair J Bush R and Ortinau D (2006) Marketing Research within a Changing Environment. $3^{\text {rd }}$ ed. (Mc Graw-Hill Irwin, New York).

Hair J Bush R and Ortinau D (2006) Marketing Research within a Changing Environment. $3^{\text {rd }}$ ed. (Mc Graw-Hill Irwin, New York).

Hayta AB (2013) A study on the effects of social media on young consumers' buying behaviours Journal of Research on Education ISSN: 2147-6284 pp. 65-74.

Hayta AB (2013) A study on the effects of social media on young consumers' buying behaviours Journal of Research on Education ISSN: 2147-6284 pp. 65-74.

Hinson ER Osarenkhoe A and Okoe AF (2013) Determinants of bank selection: A study of undergraduate students in the University of Ghana. Journal of Service Science and Management.

Hinson ER Osarenkhoe A and Okoe AF (2013) Determinants of bank selection: A study of undergraduate students in the University of Ghana. Journal of Service Science and Management.

Hinson R, Mohammed A, and Mensah R (2006). Determinants of Ghanaian bank service quality in a universal banking dispensation. Banks and Bank Systems, 1(2), 69-81.

Hinson R, Mohammed A, and Mensah R (2006). Determinants of Ghanaian bank service quality in a universal banking dispensation. Banks and Bank Systems, 1(2), 69-81.

Hinson RE, Abdul-Hamid IK, and Osabutey EL (2017) Investigating market orientation and positioning in star-rated hotels in Ghana International Journal of Contemporary Hospitality Management, 29(10), 2629-2646.

Hinson RE, Abdul-Hamid IK, and Osabutey EL (2017) Investigating market orientation and positioning in star-rated hotels in Ghana International Journal of Contemporary Hospitality Management, 29(10), 2629-2646.

Ibrahim H (2014) Young adults bank selection and loyalty decisions. Globe Edit, Saarbrucken. ISBN: 978-3-639-77083-4

Ibrahim H (2014) Young adults bank selection and loyalty decisions. Globe Edit, Saarbrucken. ISBN: 978-3-639-77083-4.

Katircioglu ST, Tumer M and Kilic C (2011) Bank selection criteria in the banking industry: An empirical investigation from customers in Romanian cities. African Journal of Business Management Vol. 5(14), pp. 5551-5558. DOI: 10.5897/AJBM 11.408 .

Katircioglu ST, Tumer M and Kilic C (2011) Bank selection criteria in the banking industry: An empirical investigation from customers in Romanian cities. African Journal of Business Management Vol. 5(14), pp. 5551-5558. DOI: 10.5897/AJBM 11.408 .

KHaitbaeva S, Al-Subaiey AA and Enyinda CI (2014) An empirical analysis of attributes influencing bank selection choices by customers in the UAE: The Dubai context. 
Middle East Conference on Global Business, Economics, Finance and Banking. ISSN: 978-1-941505-16-8, Paper ID_D4115.

KHaitbaeva S, Al-Subaiey AA and Enyinda CI (2014) An empirical analysis of attributes influencing bank selection choices by customers in the UAE: The Dubai context. Middle East Conference on Global Business, Economics, Finance and Banking. ISSN: 978-1-941505-16-8, Paper ID_D4115.

Kuada J (2012) Research methodology: A project guide for university students. Samfunds Litteratur.

Kuada J (2012) Research methodology: A project guide for university students. Samfunds Litteratur.

Lees $G$ and Winchester M (2013) Do customers profile change over time? An investigation of the success of targeting consumers of Australia's top 10 bank-2009 and 2011. Journal of Financial Services Marketing. Vo. 00,0, 1-13.

Lees G and Winchester M (2013) Do customers profile change over time? An investigation of the success of targeting consumers of Australia's top 10 bank-2009 and 2011. Journal of Financial Services Marketing. Vo. 00,0, 1-13.

Lelissa MB and Lelissa TB (2017) Determinants of bank selection choices and customer loyalty the case of Ethiopian banking sector European Journal of Business and Management. Vol. 9, No. 13 ISSN: 2222-1905.

Lelissa MB and Lelissa TB (2017) Determinants of bank selection choices and customer loyalty the case of Ethiopian banking sector European Journal of Business and Management. Vol. 9, No. 13 ISSN: 2222-1905.

Maiyaki AA (2011) Factors determining bank's selection and preference in Nigerian retail banking International Journal of Business Management, 6(1): 253-257.

Maiyaki AA (2011) Factors determining bank's selection and preference in Nigerian retail banking International Journal of Business Management, 6(1): 253-257.

Malhotra NK and Birks DF (2008) Marketing research: an applied approach. Harlow: Prentice Hall.

Malhotra NK and Birks DF (2008) Marketing research: an applied approach. Harlow: Prentice Hall.

Maudos, J (2017) Income structure, profitability and risk in the European banking sector: The Impact of the crisis Research in International Business and Finance, 39, 85-101. Morton A (2017) Disasters and dilemmas: Strategies for real-life decision making John Wiley \& Sons.

Maudos, J (2017) Income structure, profitability and risk in the European banking sector: The Impact of the crisis Research in International Business and Finance, 39, 85-101.

Morton A (2017) Disasters and dilemmas: Strategies for real-life decision making John Wiley \& Sons.

Narteh B and Owusu-Frimpong N (2011) An analysis of students' knowledge and choice criteria in retail bank selection in sub-Saharan Africa: The case of Ghana. International Journal of Bank Marketing, 29(5), 373-397.

Narteh B and Owusu-Frimpong N (2011) An analysis of students' knowledge and choice criteria in retail bank selection in sub-Saharan Africa: The case of Ghana. International Journal of Bank Marketing, 29(5), 373-397.

Nartey B and Kuada J (2014) Customer satisfaction with retail banking service in Ghana. Thunderbird International Business Review, 56 (4), 353-371.

Nartey B and Kuada J (2014) Customer satisfaction with retail banking service in Ghana. Thunderbird International Business Review, 56 (4), 353-371.

Ndubisi NO, Malhotra NK and Wah CK (2008) Relationship marketing, customer satisfaction and loyalty: a theoretical and empirical analysis from an Asian perspective. Journal of International Consumer Marketing, 21(1), 5-16. 
Ndubisi NO, Malhotra NK and Wah CK (2008) Relationship marketing, customer satisfaction and loyalty: a theoretical and empirical analysis from an Asian perspective. Journal of International Consumer Marketing, 21(1), 5-16.

Nkamnebe AD, Ukenna S, Anionwu C and Chibuike V (2014) Determinants of bank selection by university undergrads in south east Nigeria: Empirical evidence. African Journal of Economic and Management Studies. Vol. 5 Iss 3 pp. 369-382.

Nkamnebe AD, Ukenna S, Anionwu C and Chibuike V (2014) Determinants of bank selection by university undergrads in south east Nigeria: Empirical evidence. African Journal of Economic and Management Studies. Vol. 5 Iss 3 pp. 369-382.

Osayawe Ehigie B (2006) Correlates of customer loyalty to their bank: a case study in Nigeria International Journal of Bank Marketing, 24(7), 494-508.

Osayawe Ehigie B (2006) Correlates of customer loyalty to their bank: a case study in Nigeria International Journal of Bank Marketing, 24(7), 494-508.

Phuong Ta H and Yin Har K (2000) A study of bank selection decisions in Singapore using the analytical hierarchy process International Journal of Bank Marketing, 18 (4), 170-180.

Phuong Ta H and Yin Har K (2000) A study of bank selection decisions in Singapore using the analytical hierarchy process International Journal of Bank Marketing, 18 (4), 170-180.

Rao AS and Sharma RK (2010). Bank Selection Criteria Employed by MBA Students in Delhi: An Empirical Analysis Journal of Business Studies Quarterly, Vol.1, no. 2, pp.56-69.

Rao AS and Sharma RK (2010). Bank Selection Criteria Employed by MBA Students in Delhi: An Empirical Analysis Journal of Business Studies Quarterly, Vol.1, no. 2, pp.56-69.

Report from the Nordic Competition Authorities (2006) Competition in Nordic Retail Banking. No.1/2006.

Report from the Nordic Competition Authorities (2006) Competition in Nordic Retail Banking. No.1/2006.

Russo I and Confente I (2017) Customer loyalty and supply chain management: Businessto Business customer loyalty analysis Routledge.

Russo I and Confente I (2017) Customer loyalty and supply chain management: Businessto Business customer loyalty analysis Routledge.

Sayani H and Miniaoui H (2013) Determinants of bank selection in the United Arab Emirates. International Journal of Bank Marketing, 31(3), 206-228.

Sayani H and Miniaoui H (2013) Determinants of bank selection in the United Arab Emirates. International Journal of Bank Marketing, 31(3), 206-228.

Singh S Rylander RH and Mims TC (2018) Understanding credit card payment behavior among college students Journal of Financial Services Marketing Vol. 20, No. 4. ISSN: 1363-0539 DOI 10.1057/s41264-018-00420.

Singh S Rylander RH and Mims TC (2018) Understanding credit card payment behavior among college students Journal of Financial Services Marketing Vol. 20, No. 4. ISSN: 1363-0539 DOI 10.1057/s41264-018-00420.

Smith EA (2017) Evolutionary ecology and human behavior. Routledge

Smith EA (2017) Evolutionary ecology and human behavior. Routledge.

Sowunmi FA, Omigie OC and Daniel DT (2014) Consumers' perception on Ofada Rice in Ibadan North Local Government Area of go State, Nigeria Journal of Economics and Sustainable Development. 5 (16), pp. 78-86.

Sowunmi FA, Omigie OC and Daniel DT (2014) Consumers' perception on Ofada Rice in Ibadan North Local Government Area of go State, Nigeria Journal of Economics and Sustainable Development. 5 (16), pp. 78-86. 
Thiyagaraj V (2015) A study of consumer preference towards branded tea in Tiruppur City Research Paper (PG \& Research Dept. of Commerce. Chikkanna Government College, Tiruppur, India).

Thiyagaraj V (2015). A study of consumer preference towards branded tea in Tiruppur City Research Paper (PG \& Research Dept. of Commerce. Chikkanna Government College, Tiruppur, India)

\section{Internet Sources}

Capital Ghana (2017) available at: http://www.capitalgroupghana.com/NewsEvent/News/ mtn-ghana-records-gh16256b-in-mobile-money-transactions-for-2016 Retrieved in March, 2017

Ghanaweb (2019): https://www.ghanaweb.com/GhanaHomePage/business/BoG-kills-16banks-to-strengthen-Ghana-s-banking-sector-712875 Retrieved in June, 2019

Myjoyonline (2019): https://www.myjoyonline.com/business/2019/May-31st/licence-of347-microfinance-companies-revoked.php Retrieved in June, 2019 
